\title{
Analysis of the RNA virome of basal hexapods
}

\author{
Sabina Ott Rutar ${ }^{1}$, Dusan Kordis ${ }^{\text {Corresp. } 1}$ \\ ${ }^{1}$ Department of Molecular and Biomedical Sciences, Josef Stefan Institute, Ljubljana, Slovenija \\ Corresponding Author: Dusan Kordis \\ Email address: dusan.kordis@ijs.si
}

The diversity and evolution of RNA viruses has been well studied in arthropods and especially in insects. However, the diversity of RNA viruses in the basal hexapods has not been analysed yet. To better understand their diversity, evolutionary histories and genome organizations, we searched for RNA viruses in transcriptome and genome databases of basal hexapods. We discovered $\sim 40$ novel RNA viruses, some of which are also present as endogenous viral elements derived from RNA viruses. Here, we demonstrated that basal hexapods host 14 RNA viral clades that have been recently identified in invertebrates. The following RNA viral clades are associated with basal hexapods: Reo, Partiti-Picobirna, TotiChryso, Mono-Chu, Bunya-Arena, Orthomyxo, Qinvirus, Picorna-Calici, Hepe-Virga, NarnaLevi, Tombus-Noda, Luteo-Sobemo, Permutotetra and Flavi. We have found representatives of the nine RNA viral clades that are present as endogenous genomic copies in the genomes of Machilis (Monocondylia) and Catajapyx (Diplura). Our study provided a first insight into the diversity of RNA viruses in basal hexapods and demonstrated that the basal hexapods possess quite high diversity of RNA viral clades. 


\section{Analysis of the RNA virome of basal hexapods}

2

3 Sabina Ott Rutar and Dušan Kordiš

4

5

6

7

8 Corresponding Author:

9 Dušan Kordiš

10 11

12

13

14

15

16

17

18

19

20

21

22

23

24

25

26

27

28

29

30

31

32

33

34

35

36

37

38

39

Email address: dusan.kordis@ijjs.si

5

17

19

1

3

Department of Molecular and Biomedical Sciences, Josef Stefan Institute, Ljubljana, Slovenia.

Department of Molecular and Biomedical Sciences, Josef Stefan Institute, Ljubljana, Slovenia. 


\section{Abstract}

41 The diversity and evolution of RNA viruses has been well studied in arthropods and especially in

42 insects. However, the diversity of RNA viruses in the basal hexapods has not been analysed yet.

43 To better understand their diversity, evolutionary histories and genome organizations, we

44 searched for RNA viruses in transcriptome and genome databases of basal hexapods. We

45 discovered $\sim 40$ novel RNA viruses, some of which are also present as endogenous viral elements

46 derived from RNA viruses. Here, we demonstrated that basal hexapods host 14 RNA viral clades

47 that have been recently identified in invertebrates. The following RNA viral clades are associated

48 with basal hexapods: Reo, Partiti-Picobirna, Toti-Chryso, Mono-Chu, Bunya-Arena, Orthomyxo,

49 Qinvirus, Picorna-Calici, Hepe-Virga, Narna-Levi, Tombus-Noda, Luteo-Sobemo, Permutotetra

50 and Flavi. We have found representatives of the nine RNA viral clades that are present as

51 endogenous genomic copies in the genomes of Machilis (Monocondylia) and Catajapyx

52 (Diplura). Our study provided a first insight into the diversity of RNA viruses in basal hexapods

53 and demonstrated that the basal hexapods possess quite high diversity of RNA viral clades.

54

55

56

57

58

59

60

61

62

63

64

\section{Introduction}

The analysis of the invertebrate RNA virosphere uncovered a vast diversity of RNA viruses in insects, their evolutionary histories, highly diverse and dynamic genome organizations, as well as the presence of distinct RNA viromes in diverse insect lineages (Shi et al., 2016). Metazoans possess the largest diversity of RNA viruses that belong to 23 out of 24 RNA viral clades (Shi et al., 2016; Shi et al., 2018) and the majority of these data were discovered in arthropods (Shi et al., 2016; Li et al., 2015). Previously defined virus families, orders, floating genera and novel virus groups were merged together into 24 RNA viral clades. Their names reflect the presence of representative viral families or orders within each RNA viral clade (Shi et al., 2016; Shi et al., 2018). Some of the RNA viral clades are large and widespread, while the majority of them have 
65 a quite limited distribution. As demonstrated in phylogenetic analyses (Shi et al., 2016; Li et al.,

66 2015), novel data connected plant and animal RNA viral clades, offering a possible interpretation

67 for their dissemination through horizontal transfer by insect vectors (Shi et al., 2016; Li et al.,

68 2015; Dolja \& Koonin, 2018; Blanc \& Gutierrez, 2015). Insects are a rich source of the RNA

69 viral diversity because of their high taxa diversity, omnipresence and ecological interactions with

70 vertebrates and plants. Many insects are known vectors for the dissemination of RNA viruses,

71 such as mosquitoes and many plant pests (e.g. thrips, whiteflies, Hemiptera and scale insects)

72 (Whitfield, Falk \& Rotenberg, 2015; Rückert \& Ebel, 2018). However, unequal sampling of

73 RNA viruses in diverse taxonomic lineages represents a major problem in the interpretation of

74 their origins and evolution (Dolja \& Koonin, 2018).

76 Numerous arthropod groups have not been included in the extensive analyses of RNA viral

77 diversity. One of such neglected taxonomic groups are basal hexapods (the former "apterygote"

78 insects). They are an assemblage of five groups: Protura (coneheads), Collembola (springtails),

79 Diplura (two-pronged bristletails), Monocondylia: Archaeognatha (jumping bristletails) and

80 Zygentoma (bristletails, silverfish and firebrats) and represent the earliest splits of hexapod

81 lineages (Misof et al., 2014). Basal hexapods are characterized by their primary lack of wings.

82 Many basal hexapods are of great ecological and economic importance. Especially Collembola

83 play a vital role in soil and leaf litter decomposition (Rusek, 1998). Some cosmopolitan species

84 are pests, like Lepisma saccharina (Zygentoma) or the lucerna flea Sminthurus viridis

85 (Collembola). Springtails have the widest distribution of any hexapod group, occurring

86 throughout the world, including Antarctica. They are found in soil, leaf litter, logs, dung, cave, 
87 shorelines, etc. and are probably the most abundant hexapods on Earth, with up to one quarter of

88 billion individuals per square acre (Rusek, 1998).

89

90 RNA viruses in the basal hexapods have largely been ignored and were not included in the study

91 of invertebrate RNA virosphere (Shi et al., 2016). Until now, the only reported basal hexapod

92 RNA virus was an amalgavirus found in a springtail (Pyle, Keeling \& Nibert, 2017). Therefore,

93 our goal was to gather new information about the distribution and diversity of RNA viruses

94 associated with basal hexapods, the composition of their RNA virome and to compare the basal

95 hexapod RNA virome with the data from the analysed insect orders (Shi et al., 2016). Our aim

was also to evaluate the potential cases of horizontal transfer of RNA viruses between plants and

97 basal hexapods due to their involvement in the decomposition of plant material. By mining 16

98 transcriptomes (at the NCBI Transcriptome Shotgun Assembly (TSA) database) and 6 genomes

99 (at the NCBI Whole Genome Shotgun database) of basal hexapods, we identified genomes of

$100 \sim 40$ novel and diverse RNA viruses. Our study provides the first insight into the diversity of

101 RNA viruses and the composition of their RNA virome in basal hexapods. Here, we

102 demonstrated that the RNA virome of basal hexapods is rich and more diverse than that of

103 numerous large insect orders.

104

105

106

107

108

109

110

111

\section{Materials \& Methods}

\section{Discovery of RNA viruses in public transcriptomic databases}

Sequence database searches were finished in May 2019. The protein queries were RNA dependent RNA polymerase (RdRp) sequences representing every RNA virus family recognized by ICTV (Lefkowitz et al., 2018), as well as the majority of the RNA viruses that are unclassified. The protein queries were also sequences of structural proteins from diverse RNA 
112 virus families. The database analysed was the Transcriptome Shotgun Assembly (TSA) at the

113 National Center for Biotechnology Information (www.ncbi.nlm.nih.gov). To detect all available

114 representatives of the particular RNA viral family, database searches were performed iteratively.

115 Comparisons were made using the TBLASTN program (Gertz et al., 2006), with the E-value

116 cutoff set to $10^{-5}$ and default settings for other parameters. The most divergent representatives of

117 the particular RNA viral family were used as queries. All newly obtained sequences were

118 compared to reference protein sequences of all RNA viruses. Sequences yielding e-values larger

119 than $1 \mathrm{e}^{-5}$ were retained and compared to entire NCBI NR database to exclude non-viral

120 sequences. Sequences for which the top hit was a virus and sequences with no other BLASTP

121 hits in NCBI NR Db were then treated as putatively viral in origin and subject to further analysis.

122 To detect highly divergent viruses, we performed domain-based BLAST by comparing the newly

123 obtained sequences against the conserved domain database with an expected value threshold of

$1241 \times 10^{-2}$. Sequences with positive hits to the RdRp domain were retained. DNA sequences were 125 translated with the Translate program (web.expasy.org/translate/). The nucleotide sequences of 126 all basal hexapod RNA viruses are available in the Data S1 file.

127

\section{Analysis of endogenous virus elements}

129 Endogenous copies of the RNA viruses were detected using the TBLASTN algorithm against 130 basal hexapod genomes available in the Whole Genome Shotgun Database (WGS) at the NCBI, 131 using viral protein sequences as queries. The queries involved protein sequences translated from

132 both the virus genomes that were identified for the first time here as well as the reference virus 133 genomes. Comparisons were made using the TBLASTN program (Gertz et al., 2006), with the 134 E-value cutoff set to $10^{-5}$ and default settings for other parameters. For each potential 
135 endogenous virus, the query process was reversed to determine their corresponding phylogenetic

136 group. The nucleotide and amino acid sequences of EVEs are available in the Data S1 file.

137

138 Prediction of protein domains

139 In order to recognize potential protein domains in the protein sequences analysed, we used NCBI

140 CDD database (www.ncbi.nlm.nih.gov/Structure/cdd/wrpsb.cgi), by applying a cut-off E-value

141 of 0.01. Some proteins were compared against SMART (smart.embl-heidelberg.de), InterPro

142 (www.ebi.ac.uk/interpro/) and Pfam (pfam.xfam.org) protein domain databases at default

143 parameters.

144

145 Phylogenetic analysis

146 To infer the phylogenetic relationships among RNA viruses, we used their RdRp protein

147 sequences. Key representatives of the particular RNA viral family were included in the

148 phylogenetic analysis. The protein sequences of the palm subdomain of RdRps were aligned

149 using MAFFT (Katoh \& Standley, 2013). Phylogenetic trees were reconstructed using the

150 maximum likelihood (ML) method. For phylogenetic reconstruction, we used IQ-TREE with the

151 in-built automated test to choose the best substitution model for each tree (Trifinopoulos et al.,

152 2016). Branch support was computed for all trees using 100 replicates of parametric bootstrap,

153 and 1000 replicates of the approximate likelihood ratio test and ultrafast bootstrap. The iTOL

154 online tool (http://itol.embl.de/) was used for phylogenetic tree annotation (Letunic \& Bork,

155 2016).

156

157 Results

158 Discovery of novel and highly divergent RNA viruses in basal hexapods 
159 The collection of the NCBI Transcriptome Shotgun Assembly (TSA) and Whole Genome

160 Sequence (WGS) databases for basal hexapods offers an attractive possibility to obtain the first

161 insight into the diversity of their RNA viromes. We performed the analysis of RNA viruses in 16

162 transcriptomes and 6 genomes of the springtails (Collembola), silverfish (Zygentoma), diplurans

163 (Diplura) and bristletails (Monocondylia: Archeaognatha) (Table 1). 12 transcriptomes and 2

164 genomes were positive for RNA viruses, while 4 transcriptomes and 4 genomes were negative.

165 These data allowed us to identify $\sim 40$ novel and diverse virus genomes or genome fragments that

166 contained an $R d R p$ domain. We observed extensive sequence divergence of the novel RdRp

167 domains, most sharing $25-40 \%$ amino acid identity with previously described RNA viruses

168 (Table 2).

169

170 The most complete set of the RNA viruses was obtained from the springtails, due to the largest

171 number of the transcriptomes. All novel RNA viruses were compared with the known viruses in

172 the NCBI databases. In such a way, we obtained information about the RNA virus family/clade

173 they belong to and their similarity to the already known viruses. To infer their phylogenetic

174 position in the particular RNA viral clade, we used ML phylogenetic analysis. Phylogenies of

175 basal hexapod RNA viruses (Figures 1-3) demonstrated that they belong to numerous RNA viral

176 clades. The RNA viral genomes of basal hexapods have genome organizations that are very

177 similar or differ only slightly from the winged insect representatives (Figures S11-S16). Since

178 the sample processing for the preparation of transcriptomic and genomic libraries of basal

179 hexapods involved entire individuals, a substantial proportion of the viruses discovered here

180 might be associated with undigested food, gut microflora or parasites that exist within the

181 organisms investigated. However, homology searching and phylogenies show that basal hexapod 
182 associated RNA viruses are most closely related to the insect viruses. It should be noted that the

183 RNA virus sequences identified in the analysed transcriptomes of basal hexapods are their

184 "putative" viruses and specific experiments should be carried out to prove that these viruses are 185 indeed replicating in these arthropod species.

186

187 Basal hexapods possess quite a diverse RNA virome

188 We found that basal hexapods possess representatives of 14 out of 24 RNA viral clades (Table

189 3). Such RNA virome diversity is higher than that of insect orders Blattodea (5/24), Dermaptera 190 (6/24), Orthoptera (8/24), Lepidoptera (8/24) and Coleoptera (9/24). The only insect orders with 191 similar or higher diversity of their RNA viromes are Odonata (12/24), Hemiptera (13/24) and 192 Diptera (17/24) (Shi et al., 2016).

193

194 Basal hexapods possess three of the six known dsRNA viral clades: Reo, Partiti-Picobirna, and 195 Toti-Chryso (Figure 1). We found the first basal hexapod reovirus in Anurida maritima.

196 Although this genome is partial, it is segmented. Six segments of reovirus were found and 197 encode RdRp (VP1), VP2, VP3, VP4, VP5 and VP10 proteins (Data S1). This reovirus is quite 198 divergent and shows less than $25 \%$ identity in the RdRp with the described reoviruses. It is most 199 closely related to coltiviruses, significantly extending their host range (Figure 1a). We found 200 endogenized partitiviruses in the Machilis genome, they show 56\% amino acid identity with the 201 Culex mosquito partitivirus. Their RdRp has a surprisingly well conserved coding capacity. A 202 partial sequence of the partitivirus RdRp was found in the transcriptome of Thermobia 203 (Zygentoma); it has 37\% amino acid identity with the Hubei partiti-like virus 10 (Figure 1b). 204 Toti-Chryso clade has a single representative in the transcriptomes of basal hexapods, in the 
205 Tetrodontophora springtail. We obtained only an RdRp fragment, and a few coat proteins. In the

206 Toti-Chryso tree, the springtail representative groups together with the "diatom colony-

207 associated dsRNA virus 10" (Figure 1c). We found endogenized totiviruses in the Machilis

208 genome.

209

210 Basal hexapods possess representatives of four clades of the negative-stranded RNA viruses:

211 Mono-Chu, Bunya-Arena, Orthomyxo and Qinvirus (Figure 2). In the Mono-Chu clade, we

212 found only endogenized mononegaviruses in genomes of Machilis and Catajapyx that belong to

213 chuviruses (Figure 2a), nyamiviruses and rhabdoviruses (Data S1). An endogenized Bunyavirus

214 nucleoprotein was found in the genome of Machilis (Monocondylia) and shows 20-30\% amino

215 acid identity with phleboviruses (Data S1). Especially interesting was the discovery of highly

216 divergent representatives of orthomyxoviruses in Atelura and Catajapyx (Figure 2b).

217 Endogenous Catajapyx orthomyxovirus is represented only by the PB1 protein. These two novel 218 orthomyxovirus PB1 proteins show just 30\% identity with the known orthologs. In Atelura, we

219 found a nearly complete orthomyxoviral genome encoding five of the six segments (PB1, PB2,

220 PA, envelope and nucleoprotein) (Figure S11). We found a full-length representative of the

221 Qinvirus clade in springtails, in the Anurida. This sequence is quite divergent from the others

222 reported recently (Shi et al., 2016), showing just 25\% identity in the RdRp region. Anurida

223 qinvirus extends the host range of this rare viral clade from a few protostomes to the basal

224 hexapods (Figure 2c). A complete genome of the Anurida qinvirus is $7722 \mathrm{bp}$ long, which

225 represents a normal size for qinviruses. It is encoded in two segments, the larger one (5993 bp

226 long) encodes RdRp, while the smaller one (1729 bp long) encodes the putative structural protein

227 that is homologous only to the Wuhan insect virus 15 (Figure S12). 
229 In basal hexapods, we found representatives of seven out of 12 positive-stranded RNA viral 230 clades: Picorna-Calici, Hepe-Virga, Narna-Levi, Tombus-Noda, Flavi, Luteo-Sobemo and

231 Permutotetra (Figure 3). The largest diversity of the positive-stranded RNA viruses was found in 232 the Picorna-Calici clade as the representatives of four picorna lineages were found - dicistrovirus 233 (in Diplura only), iflavirus (in Diplura and Collembola), Kelp fly (in Zygentoma and 234 Collembola) and Nora-like viruses (in Monocondylia only) (Figure 3a). Few selected 235 picornaviral genomes are shown in the Figure S13. We discovered Hepe-Virga clade in 236 Collembola and Diplura, where Negev-like viruses were prevailing. In the phylogenetic analysis 237 of the Negevirus group, we included diverse representatives in basal hexapods, extending the 238 host range of this RNA viral clade (Figure 3b). The genome of the Sminthurus negev-like virus 239 is quite large $(\sim 10,6 \mathrm{~kb})$. In addition to the RdRp-encoding ORF, it possesses additional ORFs 240 with typical negevirus conserved protein domains (Figure S14). We also found a complete Benji241 like virus in Holacanthella (Collembola) transcriptome (Data S1). This virus is 45\% identical in

242 the core RdRp domain with the Hubei Beny-like virus 1, which was the first known metazoan 243 benyi-like virus and was found only in Diptera (Shi et al., 2016). Its genome is 7680 bp long and 244 encodes a single ORF with 2457 amino acids. The comparison of both metazoan benyi-like 245 viruses showed that the springtail representative possesses a large region (between amino acids 246850 and 1969) that is absent in dipteran benyi-like virus. A single incomplete narnavirus genome 247 (1133 bp long) was found in springtails (Figure 3c) and possesses a typical genome organization 248 of narnaviruses (Figure S15). Two representatives of the Tombus-Noda clade were found in 249 Zygentoma, in Atelura and Tricholepidion transcriptomes (Figure 3d). We found incomplete genomes of Tombus-like viruses in Zygentoma only (Figure S16). In the Flavi clade, we found a 
251 number of fragments of jingmenvirus in a Sminthurus springtail, they encode both NS3 and NS5

252 proteins (Data S1). In a dipluran Megajapyx, we found few permutotetravirus fragments of the

253 RdRp that show up to 59\% amino acid identity with Hubei permutotetra-like virus 9 (Data S1).

254 In the springtail Holacanthella, we found a fragment of sobemo-like virus RdRp that shows 47\%

255 amino acid identity with Hubei sobemo-like virus 17. In the transcriptome of the same species,

256 we found sobemo-like capsid that shows $33 \%$ identity with Hubei sobemo-like virus 19. In the

257 transcriptome of the Pogonognathellus springtail, we also found sobemo-like capsid (encodes

258 viral-coat domain) that shows $34 \%$ identity with bat sobemovirus (Data S1).

259

260 Endogenous viral elements are not rare in basal hexapods

261 A considerable number of endogenous viral elements (EVEs) was discovered in insect genomes

262 (Shi et al., 2016), which is an indication of past infection events (Holmes, 2011; Feschotte \&

263 Gilbert, 2012; Aiewsakun \& Katzourakis, 2015). We searched for potential EVEs in all available

264 basal hexapod genomes. We analysed RdRp proteins as well as numerous additional structural

265 proteins, such as nucleo- and glyco-proteins, for representatives of all metazoan RNA viral

266 families. EVEs in basal hexapods came from nine RNA viral clades: from Mono-Chu,

267 Orthomyxo, Qin, Partiti-Picobirna, Reo, Tombus-Noda, Hepe-Virga, Bunya-Arena and Toti-

268 Chryso (Figures 1-3; Data S1). Since the RNA viromes of basal hexapods are diverse, it is

269 interesting that they possess EVEs only in Diplura and Monocondylia genomes. Although

270 arthropods possess EVEs for 13 RNA viral clades (Hepe-Virga, Luteo-Sobemo, Narna-Levi,

271 Bunya-Arena, Mono-Chu, Orthomyxo, Nido, Partiti-Picobirna, Picorna-Calici, Reo, Tombus-

272 Noda, Toti-Chryso and Qinvirus) (Shi et al., 2016), we found that the amount and the diversity of

273 EVEs in basal hexapods is similar to them (Table 4). As expected, given their endogenous status, 
274 most of these sequences are only fragments of the parent virus genome (Figures 1-3; Data S1).

275 All EVEs in basal hexapods are integrated in random genomic loci in different species. In the

276 vicinity of EVEs in basal hexapods no retroposon elements can be found. Our analysis

277 demonstrated that EVEs are not rare in the genomes of some basal hexapods and have been 278 generated by multiple independent integration events.

279

280

\section{Composition and abundance of RNA viruses in viromes of basal hexapods}

281 The comparison of basal hexapod RNA virome composition with that of insects (Shi et al., 2016)

282 demonstrated some similarities and many differences. In both cases, Picorna-Calici clade is the

283 largest. Hepe-Virga is the major additional clade in basal hexapods. The other RNA viral clades

284 are much less abundant in the total RNA virome of basal hexapods, such as the Mono-Chu,

285 Tombus-Noda, Narna-Levi, Partiti-Picobirna, Luteo-Sobemo, Orthomyxo, Reo, Toti-Chryso,

286 Flavi, Permutotetra, Bunya-Arena and Qinvirus. Positive-stranded RNA viruses are prevailing in 287 their RNA virome, while negative-stranded and double-stranded RNA viruses are less abundant 288 in basal hexapods (Figures 1-3). It was demonstrated that the abundance and composition of 289 RNA viromes are obviously phylum-specific (Shi et al., 2016). While some RNA viral clades are 290 much more abundant in winged insects, they are quite rare in basal hexapods. The reasons for 291 such differences could be effects of biased sampling, depth and size of the RNASeq libraries, or 292 real differences in the amount of some RNA viral clades. The majority of hexapods possess very 293 similar patterns of RNA virome composition - few major RNA viral clades and numerous minor 294 clades with limited distribution (Shi et al., 2016).

295

296 Comparison of winged insect (Pterygota) and basal hexapod RNA viromes 
297 The basal position of apterygote hexapods in the hexapod tree (Misof et al., 2014) is important

298 for understanding the origin and evolution of the insect-specific RNA viruses. We can compare

299 novel basal hexapod RNA viruses with diverse relatives from winged insects. In such a way, we

300 can trace the changes in the RNA viromes, originations of particular RNA viral families etc.

301 (Table 5). It is obvious that basal hexapod and winged insect RNA viromes are similar, where

302 insects collectively possess four viral clades more (18 of the 24 RNA viral clades in total) (Shi et

303 al., 2016). It should be noted that all previously discovered insect RNA viruses were involved in

304 the phylogenetic analysis of the invertebrate RNA virosphere (Shi et al., 2016).

305

306 dsRNA virome of the basal hexapods is represented by three RNA viral clades, while winged

307 insects possess representatives of five viral clades. Some insect orders are without (Orthoptera),

308 with a single (Lepidoptera, Dermaptera and Blattodea) or with just two dsRNA viral clades

309 (Coleoptera). Insect orders with three or four RNA viral clades are Odonata, Hemiptera and

310 Diptera. As evident from the Table 5, there are differences between the insect orders in the

311 presence/absence of the particular dsRNA viral clade. A similar situation was observed in

312 negative-stranded RNA viromes where basal hexapods possess representatives of four RNA viral

313 clades. In insects, five negative-stranded RNA viral clades are present, but with unequal

314 distribution patterns in diverse insect orders. Some of these RNA viral clades are diverse and rich

315 (Mono-Chu and Bunya-Arena clades), while others are moderate (Orthomyxo) or very small

316 (Ophio and Qinvirus). Some insect orders possess a single (Coleoptera), two (Lepidoptera and

317 Dermaptera) or three RNA viral clades (Orthoptera, Blattodea, Odonata and Hemiptera). Diptera

318 is the only insect order that possesses five out of six negative-stranded RNA viral clades. Until

319 now, dipterans were the only insect order that possesses Quinvirus (Shi et al., 2016). Here, we 
320 show that qinviruses are indeed more widespread among insect orders (Figure 2). The positive-

321 stranded RNA virome in basal hexapods is represented by seven viral clades while winged

322 insects possess eight clades out of twelve. In contrast to the basal hexapods, winged insects

323 possess more diversity inside the RNA viral clades of the positive-stranded RNA virome. A

324 number of insect orders possess a smaller number of positive-stranded RNA viral clades, such as

325 Blattodea (1), Dermaptera (3), Lepidoptera (5), Orthoptera (5), Coleoptera (6) and Odonata (6).

326 Hemiptera possess seven clades, while Diptera possess eight positive-stranded RNA viral clades.

327 As in the double-stranded and negative-stranded RNA viromes, the distribution of positive-

328 stranded RNA viral clades differs among insect orders. Only some of the RNA viral clades are

329 widespread in hexapods, such as Picorna-Calici, Tombus-Noda, Mono-Chu, Bunya-Arena,

330 Orthomyxo and Permutotetra. All other RNA viral clades have a much more limited distribution.

331

332 Horizontal virus transfer is very rare in basal hexapods

333 Many insects are known vectors for the dissemination of RNA viruses, such as mosquitoes and

334 many plant pests (e.g. thrips, whiteflies, lepidopterans, coleopterans and scale insects) (Whitfield,

335 Falk \& Rotenberg, 2015; Rückert \& Ebel, 2018). Since springtails (Collembola) are very

336 abundant physical decomposers of plant and fungal material, there is a possibility of transfer of

337 plant or fungal viruses into them. Springtails could potentially act as vectors of plant or fungal

338 RNA viruses. However, the analysis of springtail transcriptomes and genomes showed that

339 horizontal virus transfer (HVT) is extremely rare among them. We found only a single short

340 fragment of a plant RNA virus in the springtail transcriptome, which could be present in ingested

341 plant material infected with this virus. This was the alfalfa mosaic virus (AMV, Bromoviridae),

342 found in the Holacanthella transcriptome (GFPE01073448, $340 \mathrm{bp}$ long fragment, 99\% amino 
343 acid identity to AMV). We were unable to find any sign of HVT in any other basal hexapod

344 lineage.

345

346 Discussion

347 The research on insect viruses has been very intensive in the last decade (Bonning, 2019). This

348 has been mostly due to the application of metagenomic and metatranscriptomic approaches

349 (Junglen \& Drosten, 2013; Liu, Chen \& Bonning, 2015; Obbard, 2018). A major breakthrough

350 has been achieved recently when a large-scale analysis of invertebrate RNA virosphere has been

351 published (Shi et al., 2016). This study extends their previous studies on negative-stranded RNA

352 viruses (Li et al, 2015) and flavivirus-like proteins (Shi et al, 2015). A large proportion of novel

353 data in these three studies was obtained from diverse insect orders. The novel picture has

354 revealed quite large differences in RNA virus diversity and their distribution patterns among

355 diverse insect orders. However, there are still numerous arthropod groups that were not included

356 in the extensive analyses of RNA viral diversity. One of these groups are basal hexapods. Until

357 now, the only reported basal hexapod RNA virus was an amalgavirus, which was found in

358 Tetrodontophora springtail but very likely originated from the microsporidian pathogen (Pyle,

359 Keeling \& Nibert, 2017). For that reason, we analysed RNA viruses in publicly available

360 transcriptomes and genomes for basal hexapods.

361

362 Here, we demonstrated that basal hexapods possess 14 out of 24 RNA viral clades, which are the 363 following: Reo, Partiti-Picobirna, Toti-Chryso, Mono-Chu, Bunya-Arena, Orthomyxo, Qinvirus,

364 Picorna-Calici, Hepe-Virga, Narna-Levi, Tombus-Noda, Luteo-Sobemo, Permutotetra and Flavi.

365 Such RNA virome diversity is similar to that of insects and is even higher than in some large

366 insect orders (Table 5). In this study, we uncovered some highly divergent viruses that have only 
$36725-30 \%$ amino acid identity in their RdRps with the known RNA viruses. These highly divergent 368 basal hexapod RNA viruses are qinvirus, reovirus, orthomyxovirus and negev-like viruses.

369 Genome organizations of the basal hexapod RNA viruses are very similar to the winged insect 370 representatives (Figures S11-S16) (Shi et al., 2016). In this study, we extended the host range for 371 some rare RNA viruses, such as qinviruses and coltivirus. In Picornavirales, we found 372 representatives of dicistroviruses, iflaviruses, Nora-like and Kelp-fly viruses. In this way, we 373 obtained novel representatives of mostly insect-specific picornaviruses. Iflaviruses seem to be 374 prevalent among basal hexapod picornaviruses. Transcriptome libraries made by selecting 375 polyadenylated RNAs might substantially bias against certain types of RNA viruses without 376 poly-A genomes. However, this was definitely not the case in basal hexapod transcriptomes, 377 since we observed besides the three polyadenylated RNA viral clades (Orthomyxo, Hepe-Virga, 378 Picorna-Calici) also nine nonpolyadenylated RNA viral clades (Partiti-Picobirna, Reo, Toti379 Chryso, Qinvirus, Luteo-Sobemo, Narna-Levi, Tombus-Noda, Flavi and Permutotetra).

381 We believe that our approach was sensitive enough to find some of the most divergent arthropod

382 RNA viruses. Due to the high divergence of basal hexapod RNA viruses, we used several 383 representatives of the particular RNA viral family or clade as queries. As a rule, we used three 384 representatives of the RNA viral clade, as defined by Shi et al. (2016), on both extremes and in 385 the middle of the tree. Instead of the default parameters in homology searching with TBlastN, we 386 also used some modified parameters to find remote homologs or very divergent RNA viruses.

387 However, in both cases we obtained the same set of RNA viruses and no extremely divergent 388 viruses. Despite this, the novel basal hexapod RNA viruses are among the most divergent 389 arthropod RNA viruses; very often they share just $22-40 \%$ identity with the already described 
390 RNA viruses. It should be noted that the closest relatives of the novel basal hexapod RNA

391 viruses are always from the arthropod hosts.

392

393 EVEs in basal hexapods came from nine RNA viral clades: Mono-Chu, Orthomyxo, Qin, Partiti394 Picobirna, Reo, Tombus-Noda, Hepe-Virga, Bunya-Arena and Toti-Chryso (Figures 1-3; Data

395 S1). Since the RNA viromes of basal hexapods are diverse, it is interesting that they possess 396 EVEs only in Diplura and Monocondylia genomes. Since whole organisms were used for the 397 preparation and sequencing of genomic DNA, there is a big chance that a number of the putative 398 EVEs are indeed RNA viruses associated with the basal hexapod hosts. However, most of the 399 EVE sequences in basal hexapod genomes are highly fragmented (Data S1), as expected for their 400 endogenous status. No retrotransposon elements can be found in the vicinity of EVEs in basal 401 hexapods. Little is known about the underlying molecular mechanisms, but sequence signatures 402 at the EVE-host genome junction point to retroposition events, suggesting involvement of the 403 enzymatic machinery encoded by retrotransposons residing in the host genome (Feschotte \& 404 Gilbert, 2012).

405

406 Basal hexapods were the earliest splits of hexapod lineages (Misof et al., 2014). The sister group 407 of hexapods are crustaceans with incredibly diverse RNA viromes, especially in marine 408 crustaceans. Land crustaceans (e.g. isopods) have a much lower abundance and diversity of their 409 RNA viromes (Shi et al., 2016). The situation seems to be similar in basal hexapods, where the 410 diversity of the RNA virome is quite high, but the abundance of the RNA viruses is lower than in 411 some large insect orders (e.g. in dipterans). Ecology (soil and plant material decomposers) and 412 the extremely high abundance of springtails (Collembola) (Rusek, 1998) offer the possibility to 
413 act as vectors in HVT (Shi et al., 2016; Li et al., 2015; Dolja \& Koonin, 2018; Blanc \&

414 Gutierrez, 2015). However, their RNA virome and RNA viruses do not show any significant 415 amount of HVT.

416

417 Many of the RNA viruses might not infect hexapods, but their parasites (Grybchuk et al., 2018).

418 The problem of finding the true host in holobiont virome analysis has already been explained

419 before (Shi et al., 2016; Dolja \& Koonin, 2018). The source of the RNA viruses in the holobiont

420 sequences might be undigested food, gut microflora or parasites that exist within the organisms

421 investigated (Shi et al., 2016). Although some insect orders (mainly Diptera, Heteroptera and

422 fleas) are infected with kinetoplastid parasites, it seems that basal hexapods are not their hosts.

423 However, diverse gregarines (Apicomplexa, Alveolata) are known to be parasites of basal

424 hexapods. At least six genera of gregarines parasitize diverse lineages of basal hexapods.

425 Currently, no sequence data are available for basal hexapod-associated gregarines.

426 Transcriptome data for gregarines are mostly from annelid or mollusk hosts. We checked the

427 diversity of the RNA viruses in gregarine transcriptomes at the NCBI TSA Db and found that at

428 least 13 RNA viral clades are associated with gregarines. These are Picorna-Calici, Hepe-Virga,

429 Tombus-Noda, Flavi, Narna-Levi, Yanvirus, Astro-Poty, Mono-Chu, Bunya-Arena, Ophio,

430 Qinvirus, Partiti-Picobirna and Toti-Chryso. A caveat should be taken into account since the

431 contaminant contigs derived from gut cells of the animal host or other organisms in the gut may

432 be present in these transcriptomes. Despite this, none of their RNA viruses is highly similar to

433 any invertebrate RNA virus. All those RNA viruses are highly divergent; some are very likely

434 novel metazoan representatives, while others may be genuine gregarine RNA viruses. Moreover,

435 none of the gregarine RNA viruses is very similar to the basal hexapod RNA viruses. Homology 
436 searching and phylogenies have shown that the basal hexapod-associated RNA viruses are most 437 closely related to the insect viruses. RNA viruses of the gregarine parasites also significantly 438 differ from arthropod sequences. We think that shared parasites can assist in the HVT of RNA 439 viruses between unrelated hosts. However, current data indicate that the HVT of RNA viruses in 440 the basal hexapods is negligible. A much larger population sampling of springtails in nature 441 could provide evidence about their role as potential vectors for the dissemination of viruses.

443 What are these viruses doing to their hosts? Although viruses are parasites, some of them might 444 be mutualists or commensals and their impact on host fitness may be negligible (Obbard, 2018;

445 Cadwell, 2015; Virgin, 2014; Roossinck, 2011). We were unable to determine whether the 446 viruses identified here have any impact on host biology, including as agents of disease. Despite 447 this, it is clear that for many metazoans infection by multiple RNA viruses is likely to be the 448 norm rather than the exception (Shi et al., 2016; Shi et al., 2018).

\section{Conclusions}

451 Our study demonstrated that basal hexapods possess quite a diverse RNA virome and some 452 highly divergent RNA viruses. Going forward, the 1KITE (www.1kite.org) and i5K 453 (arthropodgenomes.org/wiki/i5K/) projects will generate numerous additional genomes and 454 transcriptomes for understudied basal hexapods. These new data may provide additional insights 455 into the RNA virome of the basal hexapod lineages.

456

457

458 The authors thank Prof. Roger H. Pain for his critical reading of the manuscript. Our sincere

459 thanks go to Dr. Jernej Šribar for his technical assistance. This work was supported by the 460 Slovenian Research Agency grant P1-0207. 
461

462

463

464

465

466

467

468

469

470

471

472

473

474

475

476

477

478

479

480

481

482

483

484

\section{References}

Aiewsakun, P.; Katzourakis, A. Endogenous viruses: Connecting recent and ancient viral evolution. Virology 2015, 479-480, 26-37.

Blanc, S.; Gutierrez, S. The specifics of vector transmission of arboviruses of vertebrates and plants. Curr. Opin. Virol. 2015, 15, 27-33.

Bonning, B.C. The Insect Virome: Opportunities and Challenges. Curr Issues Mol Biol. 2019, $34,1-12$.

Cadwell, K. The virome in host health and disease. Immunity 2015, 42, 805-813.

Dolja, V.V.; Koonin, E.V. Metagenomics reshapes the concepts of RNA virus evolution by revealing extensive horizontal virus transfer. Virus Res. 2018, 244, 36-52.

Feschotte, C.; Gilbert, C. Endogenous viruses: insights into viral evolution and impact on host biology. Nat. Rev. Genet. 2012, 13, 283-296.

Gertz, E.M.; Yu, Y.K.; Agarwala, R.; Schäffer, A.A.; Altschul, S.F. Composition-based statistics and translated nucleotide searches: improving the TBLASTN module of BLAST. BMC Biol. 2006, 4, 41 .

Grybchuk, D.; Akopyants, N.S.; Kostygov, A.Y.; Konovalovas, A.; Lye, L.F.; Dobson, D.E.; Zangger, H.; Fasel, N.; Butenko, A.; Frolov, A.O.; Votýpka, J.; d'Avila-Levy, C.M.; Kulich, P.; Moravcová, J.; Plevka, P.; Rogozin, I.B.; Serva, S.; Lukeš, J.; Beverley, S.M.; Yurchenko, V. Viral discovery and diversity in trypanosomatid protozoa with a focus on relatives of the human parasite Leishmania. Proc Natl Acad Sci USA. 2018, 115, E506E515.

Holmes, E.C. The evolution of endogenous viral elements. Cell Host Microbe 2011, 10, 368377. 
485 Junglen, S.; Drosten, C. Virus discovery and recent insights into virus diversity in arthropods. 486 Curr Opin Microbiol. 2013, 16, 507-513.

487 Katoh, K., Standley, D.M. MAFFT multiple sequence alignment software version 7:

488 improvements in performance and usability. Mol Biol Evol. 2013, 30, 772-780.

489 Lefkowitz, E.J., Dempsey, D.M., Hendrickson, R.C., Orton, R.J., Siddell, S.G., Smith, D.B.

490 Virus taxonomy: the database of the International Committee on Taxonomy of Viruses

491 (ICTV). Nucleic Acids Res. 2018, 46 (D1), D708-D717.

492 Letunic, I.; Bork, P. Interactive tree of life (iTOL) v3: an online tool for the display and 493 annotation of phylogenetic and other trees. Nucleic Acids Res. 2016, 44(W1), W242-

$494 \quad$ W245.

495 Li, C.X.; Shi, M.; Tian, J.H.; Lin, X.D.; Kang, Y.J.; Chen, L.J.; Qin, X.C.; Xu, J.; Holmes, E.C.;

496 Zhang, Y.Z. Unprecedented genomic diversity of RNA viruses in arthropods reveals the 497 ancestry of negative-sense RNA viruses. eLife 2015, 4, e05378.

498 Liu, S.; Chen, Y; Bonning, B.C. RNA virus discovery in insects. Curr Opin Insect Sci. 2015, 8, $499 \quad 54-61$.

500 Misof, B.; Liu, S.; Meusemann, K.; Peters, R.S.; Donath, A.; Mayer, C.; Frandsen, P.B.; Ware, 501

502

503

504

505

506

507 J.; Flouri, T.; Beutel, R.G.; Niehuis, O.; Petersen, M.; Izquierdo-Carrasco, F.; Wappler, T.; Rust, J.; Aberer, A.J.; Aspöck, U.; Aspöck, H.; Bartel, D.; Blanke, A.; Berger, S.; Böhm, A.; Buckley, T.R.; Calcott, B.; Chen, J.; Friedrich, F.; Fukui, M.; Fujita, M.; Greve, C.; Grobe, P.; Gu, S.; Huang, Y.; Jermiin, L.S.; Kawahara, A.Y.; Krogmann, L.; Kubiak, M.; Lanfear, R.; Letsch, H.; Li, Y.; Li, Z.; Li, J.; Lu, H.; Machida, R.; Mashimo, Y.; Kapli, P.; McKenna, D.D.; Meng, G.; Nakagaki, Y.; Navarrete-Heredia, J.L.; Ott, M.; Ou, Y.; Pass, G.; Podsiadlowski, L.; Pohl, H.; von Reumont, B.M.; Schütte, K.; Sekiya, K.; Shimizu, S.; 
508

509

510

511

512

513

514

515

516

517

518

519

520

521

522

523

524

525

526

527

528

529

Slipinski, A.; Stamatakis, A.; Song, W.; Su, X.; Szucsich, N.U.; Tan, M.; Tan, X.; Tang, M.; Tang, J.; Timelthaler, G.; Tomizuka, S.; Trautwein, M.; Tong, X.; Uchifune, T.; Walzl, M.G.; Wiegmann, B.M.; Wilbrandt, J.; Wipfler, B.; Wong, T.K.; Wu, Q.; Wu, G.; Xie, Y.; Yang, S.; Yang, Q.; Yeates, D.K.; Yoshizawa, K.; Zhang, Q.; Zhang, R.; Zhang, W.; Zhang, Y.; Zhao, J.; Zhou, C.; Zhou, L.; Ziesmann, T.; Zou, S.; Li, Y.; Xu, X.; Zhang, Y.; Yang, H.; Wang, J.; Wang, J.; Kjer, K.M.; Zhou, X. Phylogenomics resolves the timing and pattern of insect evolution. Science 2014, 346, 763-767.

Obbard, D.J. Expansion of the metazoan virosphere: progress, pitfalls, and prospects. Curr Opin Virol. 2018, 31, 17-23.

Pyle, J.D.; Keeling, P.J.; Nibert, M.L. Amalga-like virus infecting Antonospora locustae, a microsporidian pathogen of grasshoppers, plus related viruses associated with other arthropods. Virus Res. 2017, 233, 95-104.

Roossinck, M.J. The good viruses: viral mutualistic symbioses. Nat. Rev. Microbiol. 2011, 9, 99108.

Rusek, J. Biodiversity of Collembola and their functional role in the ecosystem. Biodivers. Conserv. 1998, 7, 1207-1219.

Rückert, C.; Ebel, G.D. How Do Virus-Mosquito Interactions Lead to Viral Emergence? Trends Parasitol. 2018, 34, 310-321.

Shi, M.; Lin, X.D.; Vasilakis, N.; Tian, J.H.; Li, C.X.; Chen, L.J.; Eastwood, G.; Diao, X.N.; Chen, M.H.; Chen, X.; Qin, X.C.; Widen, S.G.; Wood, T.G.; Tesh, R.B.; Xu, J.; Holmes, E.C.; Zhang, Y.Z. Divergent Viruses Discovered in Arthropods and Vertebrates Revise the Evolutionary History of the Flaviviridae and Related Viruses. J Virol. 2015, 90, 659-669. 
530 Shi, M.; Lin, X.D.; Tian, J.H.; Chen, L.J.; Chen, X.; Li, C.X.; Qin, X.C.; Li, J.; Cao, J.P.; Eden, $531 \quad$ J.S.; Buchmann, J.; Wang, W.; Xu, J.; Holmes, E.C.; Zhang, Y.Z. Redefining the 532 invertebrate RNA virosphere. Nature 2016, 540, 539-543.

533 Shi, M.; Lin, X.D.; Chen, X.; Tian, J.H.; Chen, L.J.; Li, K.; Wang, W.; Eden, J.S.; Shen, J.J.;

534 Liu, L.; Holmes, E.C.; Zhang, Y.Z. The evolutionary history of vertebrate RNA viruses. $535 \quad$ Nature 2018, 556, 197-202.

536 Trifinopoulos, J.; Nguyen, L.T.; von Haeseler, A.; Minh, B.Q. W-IQ-TREE: a fast online 537 phylogenetic tool for maximum likelihood analysis. Nucleic Acids Res. 2016, 44(W1), $538 \quad$ W232-W235.

539 Virgin, H.W. The virome in mammalian physiology and disease. Cell 2014, 157, 142-150.

540 Whitfield, A.E.; Falk, B.W.; Rotenberg, D. Insect vector-mediated transmission of plant viruses. 541 Virology 2015, 479-480, 278-289. 


\section{Figure 1}

Double stranded RNA viruses.

These midpoint-rooted, maximum-likelihood trees were inferred from viral RdRp protein sequences. The names of the viruses are marked with different colours based on their host taxonomy; springtails (Collembola) are red, Diplura are violet, Monocondylia are green, and Zygentoma are blue. The star symbol denotes host taxa that contain endogenous viral elements (EVEs). Sequences from the Shi et al. (2016) have the same unique accession numbers as in the original publication. Tree A) reoviruses from the Reo clade; tree $B$ ) partitiviruses from the Partiti-Picobirna clade; tree C) totiviruses from the Toti-Chryso clade. Complete trees are provided in Figures S1 to S3. 
A

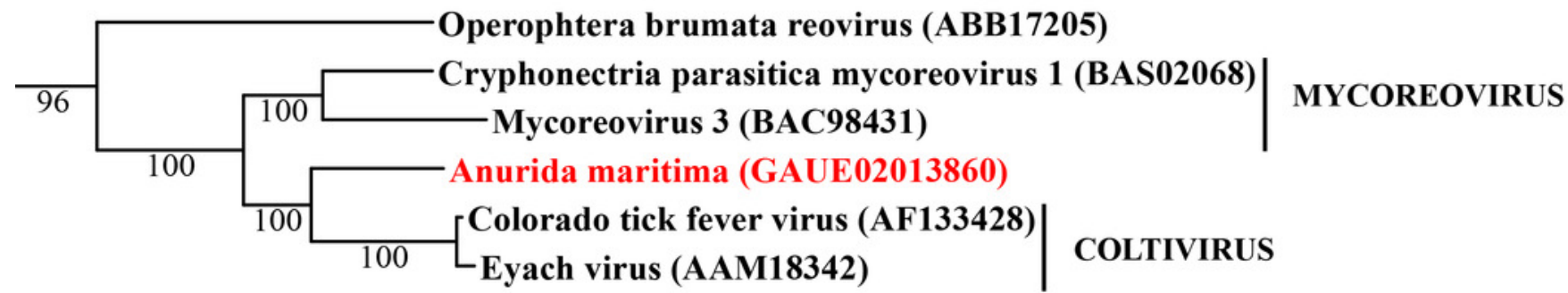

B
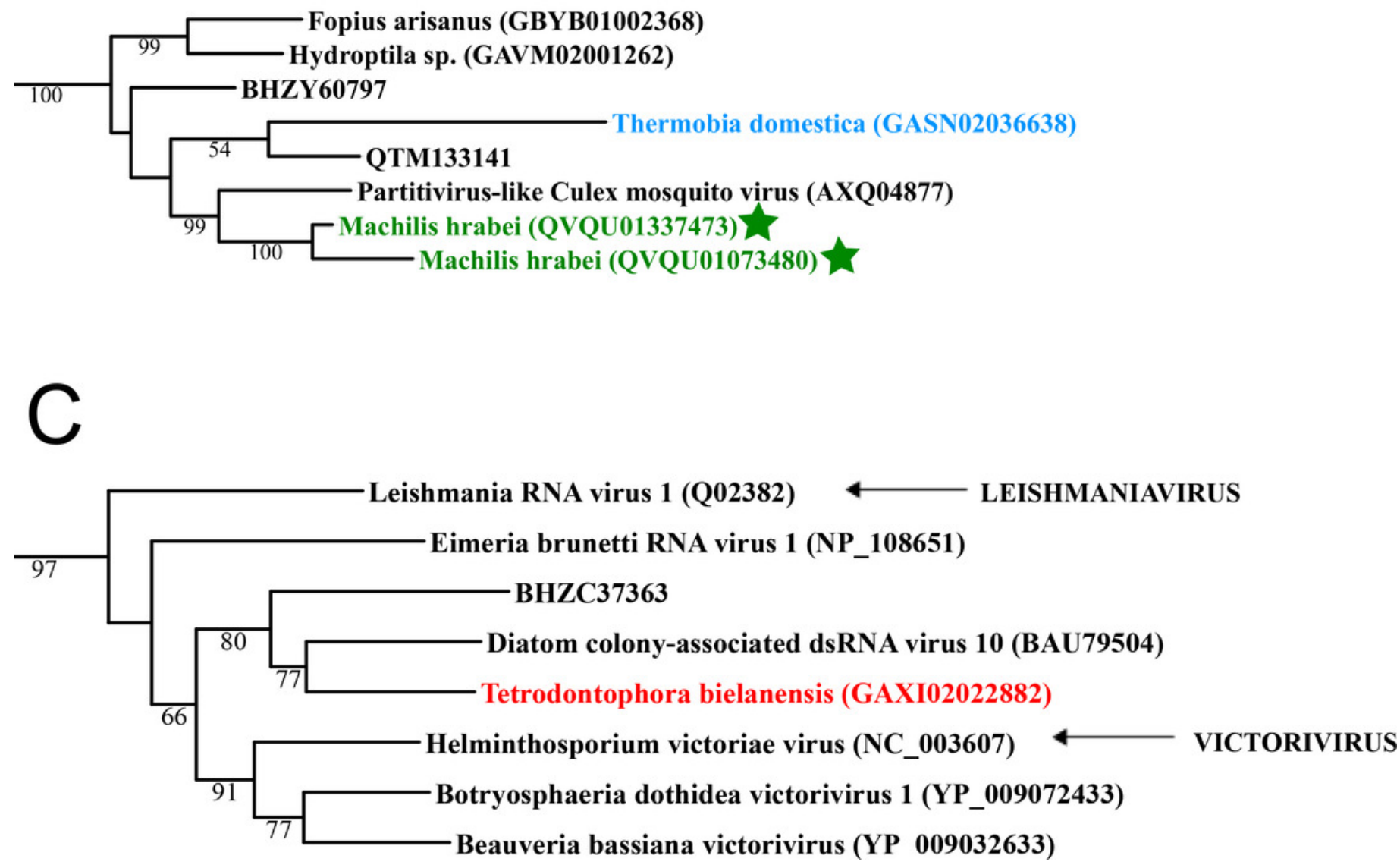


\section{Figure 2}

Negative-stranded RNA viruses.

Midpoint-rooted, maximum-likelihood trees were inferred from viral RdRp protein sequences. The names of the viruses are marked with different colours based on their host taxonomy; springtails (Collembola) are red, Diplura are violet, Monocondylia are green, and Zygentoma are blue. The star symbol denotes host taxa that contain endogenous viral elements (EVES). Sequences from the Shi et al. (2016) have the same unique accession numbers as in the original publication. Tree A) chuvirus from the Mono-Chu clade; tree B) viruses belonging to Orthomyxo clade; tree C) viruses belonging to Qinvirus clade. Complete trees are provided in Figures S4 to S6. 
A

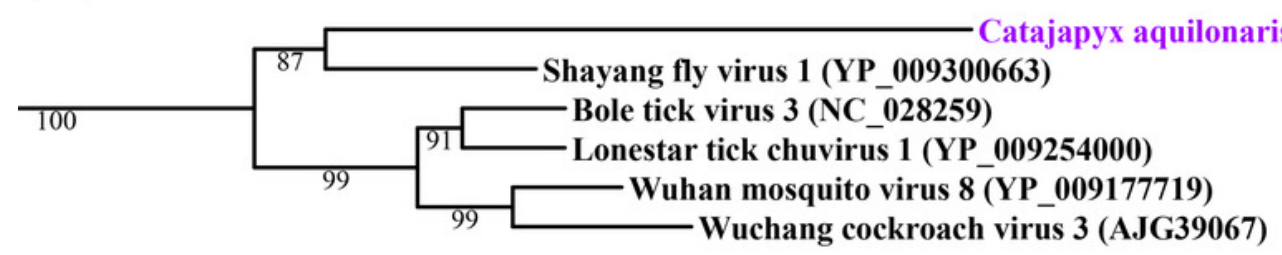

CHUVIRUS

\section{B}
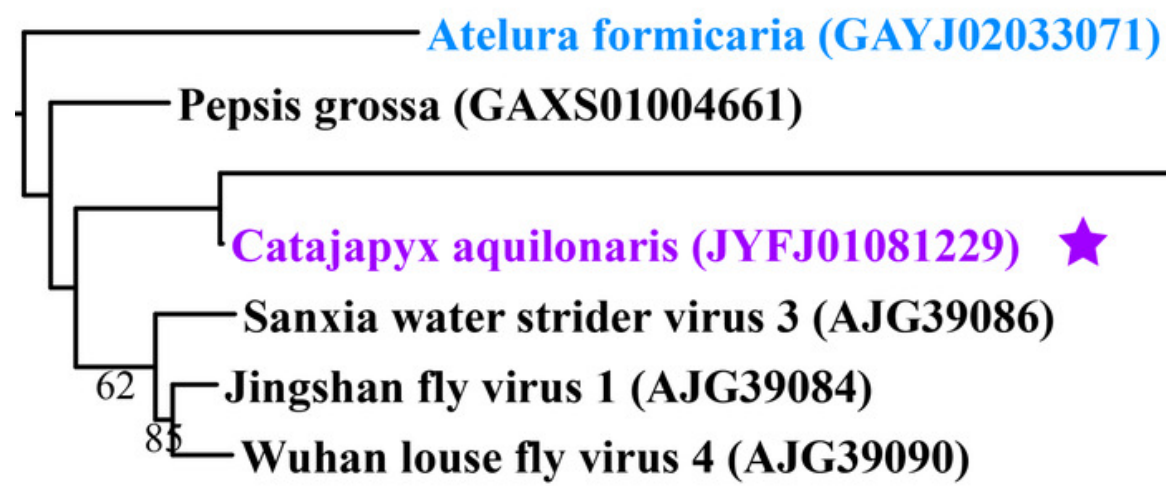

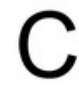
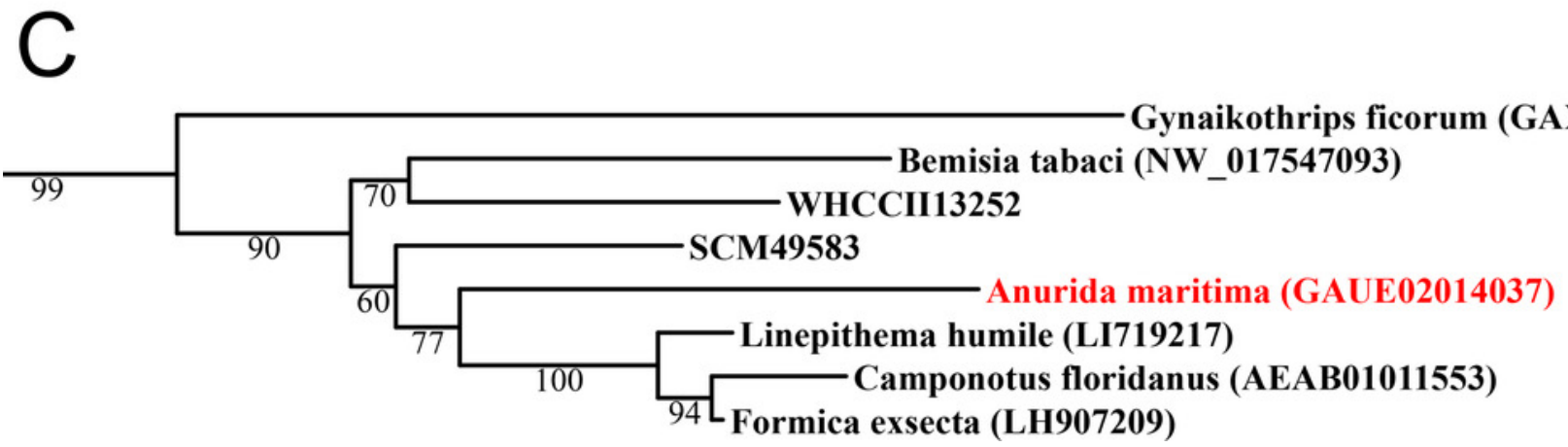


\section{Figure 3}

Positive-stranded RNA viruses.

Midpoint-rooted, maximum-likelihood trees were inferred from viral RdRp protein sequences. The names of the viruses are marked with different colours based on their host taxonomy; springtails (Collembola) are red, Diplura are violet, Monocondylia are green, and Zygentoma are blue. The star symbol denotes host taxa that contain endogenous viral elements (EVEs). Viruses previously described as EVEs are also marked. Sequences from the Shi et al. (2016) have the same unique accession numbers as in the original publication. Tree A) viruses belonging to Nora virus, Posavirus and Kelp fly virus lineages from Picorna-Calici clade; tree B) viruses belonging to iflavirus and dicistrovirus lineages from Picorna-Calici clade; tree C) viruses belonging to the Negeviruses from the Hepe-Virga clade; tree $\mathrm{D}$ ) viruses belonging to the Narnaviruses from the Narna-Levi clade; tree E) viruses belonging to the tombus-like viruses from the Tombus-Noda clade. Complete trees are provided in Figures S7 to S10. 


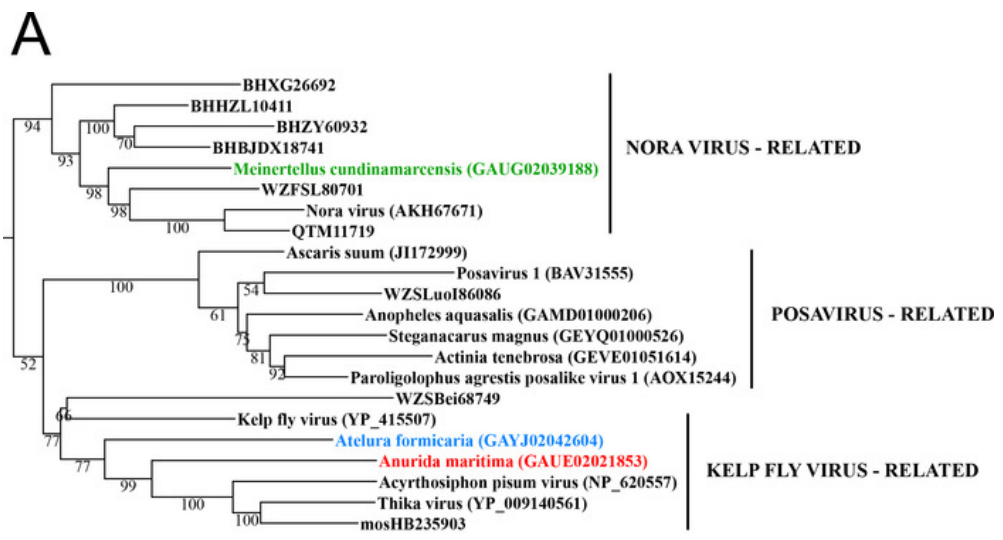

B

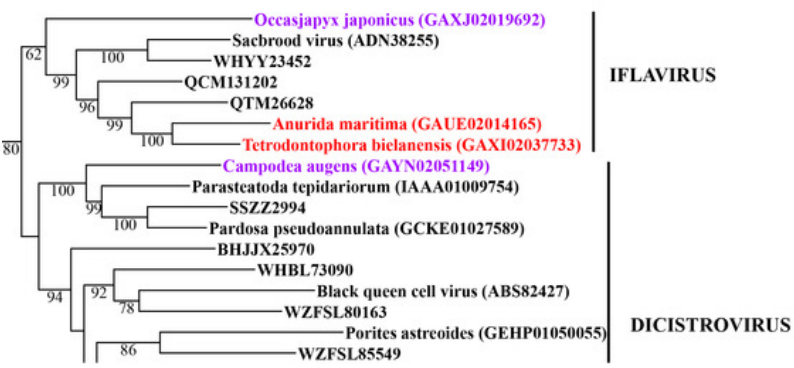

C

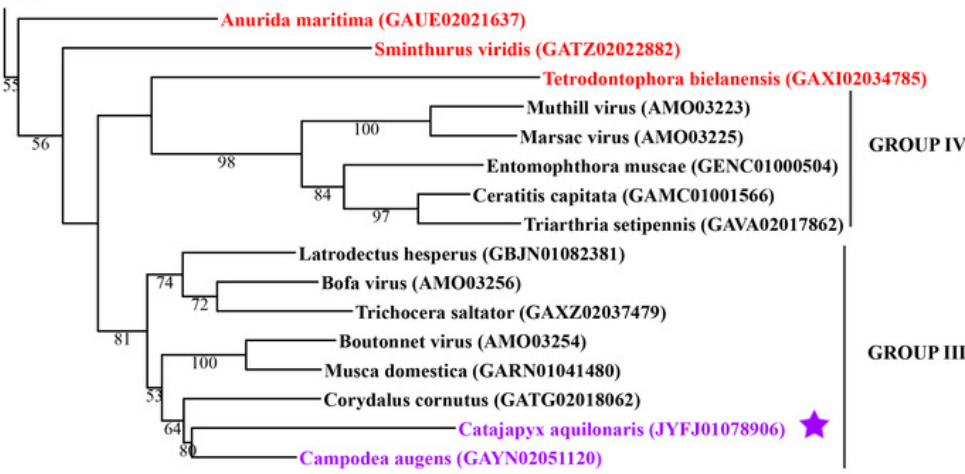

$\mathrm{D}$

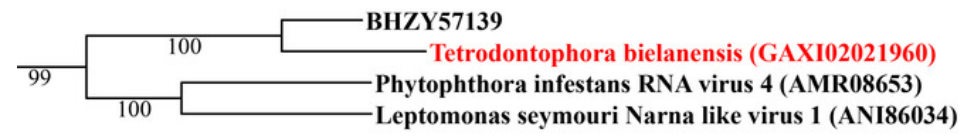

E

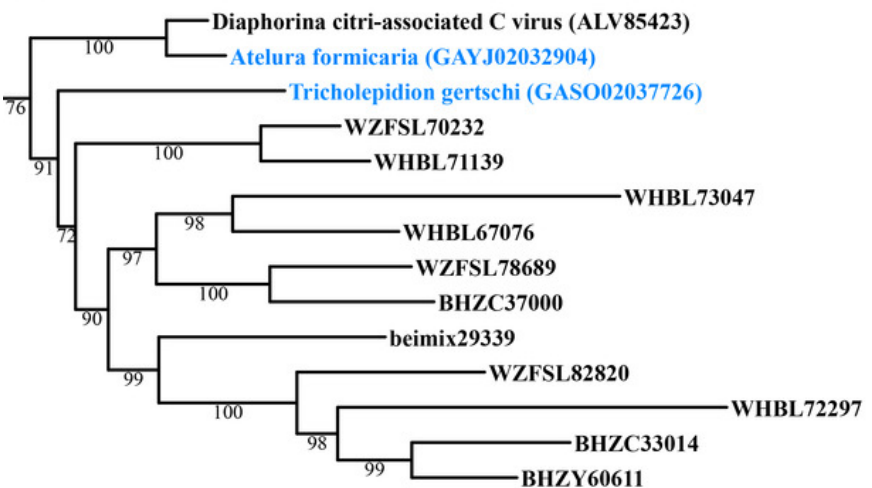

Peer) reviewing PDF | (2019:10:41897:1:1:NEW 27 Nov 2019) 


\section{Table $\mathbf{1}$ (on next page)}

List of analysed basal hexapods in the NCBI transcriptome (TSA) and genome (WGS) databases. 
Table 1. List of analysed basal hexapods in the NCBI transcriptome (TSA) and genome (WGS) databases.

\begin{tabular}{|c|c|c|c|c|}
\hline $\begin{array}{c}\text { Basal hexapod } \\
\text { lineage }\end{array}$ & Species & Transcriptome & $\begin{array}{l}\text { Number of linear } \\
\text { transcribed-RNAs }\end{array}$ & Genome \\
\hline \multirow[t]{8}{*}{ Collembola } & Anurida maritima & GAUE02000000 & 22076 & \\
\hline & Sminthurus viridis & GATZ00000000 & 32669 & \\
\hline & $\begin{array}{l}\text { Tetrodontophora } \\
\text { bielanensis }\end{array}$ & GAXI00000000 & 46137 & \\
\hline & Folsomia candida & GAMN00000000 & 38,102 & LNIX00000000 \\
\hline & Orchesella cincta & GAMM00000000 & 32,460 & LJIJ00000000 \\
\hline & Pogonognathellus sp. & GATD00000000 & 37079 & \\
\hline & $\begin{array}{l}\text { Holacanthella } \\
\text { duospinosa }\end{array}$ & GFPE00000000 & 86369 & NIPM00000000 \\
\hline & Sinella curviseta & GGYG00000000 & 27976 & RBVU00000000 \\
\hline \multirow[t]{3}{*}{ Zygentoma } & Atelura formicaria & GAYJ00000000 & 51705 & \\
\hline & Thermobia domestica & GASN00000000 & 68388 & \\
\hline & $\begin{array}{l}\text { Tricholepidion } \\
\text { gertschi }\end{array}$ & GASO00000000 & 49924 & \\
\hline \multirow[t]{4}{*}{ Diplura } & Catajapyx aquilonaris & & & JYFJ02000000 \\
\hline & Occasjapyx japonicus & GAXJ00000000 & 26221 & \\
\hline & Campodea augens & GAYN00000000 & 64149 & \\
\hline & $\begin{array}{l}\text { Megajapyx sp. } \\
\text { UVienna-2012 }\end{array}$ & SRR400673 & 57,602 & \\
\hline \multirow[t]{2}{*}{ Monocondylia } & Machilis hrabei & GAUM00000000 & 44661 & QVQU01000000 \\
\hline & $\begin{array}{c}\text { Meinertellus } \\
\text { cundinamarcensis }\end{array}$ & GAUG00000000 & 56838 & \\
\hline
\end{tabular}


Table 2 (on next page)

List of RNA viruses discovered in basal hexapods. 
Table 2 List of RNA viruses discovered in basal hexapods.

\begin{tabular}{|c|c|c|c|c|c|c|c|c|}
\hline Putative host & $\begin{array}{c}\text { NCBI accession } \\
\text { number }\end{array}$ & $\begin{array}{c}\text { Virus } \\
\text { genome } \\
\text { length (bp) }\end{array}$ & $\begin{array}{l}\text { Length of } \\
\text { RdRp (aa) }\end{array}$ & $\begin{array}{c}\text { Virus } \\
\text { classification } \\
\text { (clade) }\end{array}$ & $\begin{array}{l}\text { Closest } \\
\text { relative }\end{array}$ & $\begin{array}{c}\text { Amino } \\
\text { acid } \\
\text { identity } \\
(\%) \\
\end{array}$ & E value & $\begin{array}{c}\text { Query } \\
\text { cover }(\%)\end{array}$ \\
\hline Anurida maritima & GAUE02021853 & 9648 & 3144 & $\begin{array}{l}\text { Picorna- } \\
\text { Calici }\end{array}$ & Thika virus & 22 & $2 e^{-49}$ & 60 \\
\hline Anurida maritima & GAUE02014165 & 8391 & 2106 & $\begin{array}{l}\text { Picorna- } \\
\text { Calici }\end{array}$ & Carfax virus & 32 & 0.0 & 83 \\
\hline $\begin{array}{c}\text { Atelura } \\
\text { formicaria }\end{array}$ & GAYJ02042604 & 5717 & 1867 & $\begin{array}{l}\text { Picorna- } \\
\text { Calici }\end{array}$ & $\begin{array}{l}\text { Hubei } \\
\text { picorna-like } \\
\text { virus } 53\end{array}$ & 27 & $8 e^{-53}$ & 35 \\
\hline $\begin{array}{c}\text { Meinertellus } \\
\text { cundinamarcensis }\end{array}$ & GAUG02039188 & 5753 & 1885 & $\begin{array}{l}\text { Picorna- } \\
\text { Calici }\end{array}$ & $\begin{array}{c}\text { Mayfield } \\
\text { virus } 1\end{array}$ & 38 & $6 e^{-92}$ & 48 \\
\hline $\begin{array}{l}\text { Occasjapyx } \\
\text { japonicus }\end{array}$ & GAXJ02019692 & 7941 & 2616 & $\begin{array}{l}\text { Picorna- } \\
\text { Calici }\end{array}$ & $\begin{array}{c}\text { Hubei } \\
\text { picorna-like } \\
\text { virus } 48\end{array}$ & 26 & $1 e^{-69}$ & 30 \\
\hline $\begin{array}{c}\text { Tetrodontophora } \\
\text { bielanensis }\end{array}$ & GAXI02037733 & 5471 & 1773 & $\begin{array}{l}\text { Picorna- } \\
\text { Calici }\end{array}$ & $\begin{array}{c}\text { Kinkell } \\
\text { virus }\end{array}$ & 35 & $8 e^{-167}$ & 89 \\
\hline $\begin{array}{l}\text { Campodea } \\
\text { augens }\end{array}$ & GAYN02051149 & 2753 & 861 & $\begin{array}{l}\text { Picorna- } \\
\text { Calici }\end{array}$ & Baker virus & 32 & $1 \mathrm{e}^{-89}$ & 73 \\
\hline $\begin{array}{l}\text { Sminthurus } \\
\quad \text { viridis }\end{array}$ & GATZ02022882 & 10627 & 2546 & Hepe-Virga & $\begin{array}{l}\text { Big Cypress } \\
\text { virus }\end{array}$ & 29 & $5 e^{-97}$ & 58 \\
\hline Anurida maritima & GAUE02021637 & 9420 & 2837 & Hepe-Virga & Negev virus & 32 & $1 e^{-137}$ & 52 \\
\hline $\begin{array}{c}\text { Campodea } \\
\text { augens }\end{array}$ & GAYN02051120 & 2383 & 216 & Hepe-Virga & $\begin{array}{l}\text { Hubei } \\
\text { virga-like } \\
\text { virus } 11\end{array}$ & 48 & $1 e^{-54}$ & 95 \\
\hline $\begin{array}{c}\text { Tetrodontophora } \\
\text { bielanensis }\end{array}$ & GAXI02034785 & 1239 & 237 & Hepe-Virga & $\begin{array}{l}\text { Hibiscus } \\
\text { green spot } \\
\text { virus } 2\end{array}$ & 41 & $9 e^{-33}$ & 71 \\
\hline $\begin{array}{c}\text { Holacanthella } \\
\text { duospinosa }\end{array}$ & GFPE01052446 & 7680 & 2457 & Hepe-Virga & $\begin{array}{c}\text { Hubei } \\
\text { Beny-like } \\
\text { virus } 1\end{array}$ & 41 & 0.0 & 54 \\
\hline $\begin{array}{c}\text { Atelura } \\
\text { formicaria }\end{array}$ & GAYJ02032904 & 2190 & 529 & $\begin{array}{l}\text { Tombus- } \\
\text { Noda }\end{array}$ & $\begin{array}{l}\text { Cushing } \\
\text { virus }\end{array}$ & 43 & $1 \mathrm{e}^{-140}$ & 97 \\
\hline
\end{tabular}




\begin{tabular}{|c|c|c|c|c|c|c|c|c|}
\hline $\begin{array}{l}\text { Tricholepidion } \\
\text { gertschi }\end{array}$ & GASO02037726 & 1773 & 577 & $\begin{array}{l}\text { Tombus- } \\
\text { Noda }\end{array}$ & $\begin{array}{l}\text { Hubei } \\
\text { mosquito } \\
\text { virus } 4\end{array}$ & 28 & $6 e^{-22}$ & 67 \\
\hline $\begin{array}{l}\text { Tetrodontophora } \\
\text { bielanensis }\end{array}$ & GAXI02021960 & 1133 & 377 & Narna-Levi & $\begin{array}{l}\text { Wilkie } \\
\text { narna-like } \\
\text { virus } 2\end{array}$ & 43 & $4 e^{-82}$ & 99 \\
\hline Anurida maritima & GAUE02014037 & 5993 & 1888 & Qinvirus & $\begin{array}{c}\text { Hubei } \\
\text { qinvirus- } \\
\text { like virus } 1\end{array}$ & 31 & 0.0 & 85 \\
\hline $\begin{array}{l}\text { Atelura } \\
\text { formicaria }\end{array}$ & GAYJ02033071 & 2485 & 803 & Orthomyxo & $\begin{array}{c}\text { Sanxia } \\
\text { Water } \\
\text { Strider } \\
\text { Virus } 3\end{array}$ & 31 & $4 \mathrm{e}^{-107}$ & 97 \\
\hline $\begin{array}{l}\text { Catajapyx } \\
\text { aquilonaris }\end{array}$ & JYFJ01081229 & - & 251 & Orthomyxo & $\begin{array}{l}\text { Jingshan } \\
\text { Fly Virus } 1\end{array}$ & 46 & $9 \mathrm{e}^{-67}$ & 98 \\
\hline Machilis hrabei & QVQU01083516 & 7956 & 1392 & Mono-Chu & $\begin{array}{c}\text { Tacheng } \\
\text { Tick Virus } \\
6\end{array}$ & 28 & $2 e^{-99}$ & 75 \\
\hline Machilis hrabei & QVQU01249695 & 8568 & 941 & Mono-Chu & $\begin{array}{c}\text { Hubei } \\
\text { chuvirus- } \\
\text { like virus } 4\end{array}$ & 40 & 0.0 & 96 \\
\hline Anurida maritima & GAUE01055186 & 4248 & 1409 & Reo & $\begin{array}{l}\text { Shelly } \\
\text { headland } \\
\text { virus }\end{array}$ & 35 & 0.0 & 98 \\
\hline $\begin{array}{l}\text { Thermobia } \\
\text { domestica }\end{array}$ & GASN02036638 & 601 & 194 & $\begin{array}{l}\text { Partiti- } \\
\text { Picobirna }\end{array}$ & $\begin{array}{c}\text { Hubei } \\
\text { partiti-like } \\
\text { virus } 10\end{array}$ & 37 & $1 \mathrm{e}^{-28}$ & 100 \\
\hline Machilis hrabei & QVQU01337473 & 3397 & 478 & $\begin{array}{l}\text { Partiti- } \\
\text { Picobirna }\end{array}$ & $\begin{array}{l}\text { Partitivirus- } \\
\text { like Culex } \\
\text { mosquito } \\
\text { virus }\end{array}$ & 56 & $4 e^{-177}$ & 90 \\
\hline $\begin{array}{l}\text { Tetrodontophora } \\
\text { bielanensis }\end{array}$ & GAXI02022882 & 1303 & 434 & Toti-Chryso & $\begin{array}{c}\text { Diatom } \\
\text { colony } \\
\text { associated } \\
\text { dsRNA } \\
\text { virus } 11 \\
\end{array}$ & 38 & $2 e^{-84}$ & 99 \\
\hline
\end{tabular}




\section{Table 3 (on next page)}

RNA viromes in basal hexapod lineages 
1 Table 3. RNA viromes in basal hexapod lineages

2

\begin{tabular}{|c|c|c|c|c|c|}
\hline $\begin{array}{c}\text { RNA viral } \\
\text { clade }\end{array}$ & $\begin{array}{c}\text { Basal } \\
\text { hexapods }\end{array}$ & Collembola & Diplura & Zygentoma & Monocondylia \\
\hline \multicolumn{6}{|l|}{ Birna } \\
\hline Partiti- & $\bullet$ & & & $\bullet$ & $\bullet$ \\
\hline \multicolumn{6}{|l|}{ Picobirna } \\
\hline Reo & $\bullet$ & $\bullet$ & & & $\bullet$ \\
\hline Toti-Chryso & $\bullet$ & $\bullet$ & & & $\bullet$ \\
\hline \multicolumn{6}{|l|}{ Нуро } \\
\hline \multicolumn{6}{|l|}{ Cystovir } \\
\hline $\begin{array}{l}\text { Bunya- } \\
\text { Arena }\end{array}$ & $\bullet$ & & & & $\bullet$ \\
\hline $\begin{array}{c}\text { Mono-Chu } \\
\text { Ophio }\end{array}$ & \multicolumn{4}{|c|}{ Ophio } & $\bullet$ \\
\hline \multirow{2}{*}{\multicolumn{6}{|c|}{$\begin{array}{c}\text { Orthomyxo } \\
\text { Qinvirus }\end{array}$}} \\
\hline & & $\bullet$ & & & $\bullet$ \\
\hline \multicolumn{6}{|l|}{ Yuevirus } \\
\hline \multicolumn{6}{|l|}{ Hepe-Virga } \\
\hline \multirow{2}{*}{\multicolumn{6}{|c|}{$\begin{array}{l}\text { Luteo- } \\
\text { Sobemo }\end{array}$}} \\
\hline & & & & & \\
\hline \multicolumn{6}{|l|}{ Narna-Levi } \\
\hline \multirow{2}{*}{\multicolumn{6}{|c|}{$\begin{array}{l}\text { Picorna- } \\
\text { Calici } \\
\text { Nido }\end{array}$}} \\
\hline & & & & & \\
\hline \multirow{3}{*}{\multicolumn{6}{|c|}{$\begin{array}{l}\text { Tombus- } \\
\text { Noda } \\
\text { Weivirus } \\
\text { Astro-Poty }\end{array}$}} \\
\hline & & & & & \\
\hline & & & & & \\
\hline Astro-Poty & & & & & \\
\hline \multirow{4}{*}{$\begin{array}{c}\text { Flavi } \\
\text { Permutotetra } \\
\text { Yanvirus } \\
\text { Zhaovirus }\end{array}$} & $\bullet$ & $\bullet$ & & & \\
\hline & $\bullet$ & & $\bullet$ & & \\
\hline & & & & & \\
\hline & $14 / 24$ & $8 / 24$ & $5 / 24$ & $4 / 24$ & $8 / 24$ \\
\hline
\end{tabular}

4 Note. - The presence of RNA viral clade is marked with the black dot. 


\section{Table 4(on next page)}

Endogenous viral elements in basal hexapod genomes 
1 Table 4. Endogenous viral elements in basal hexapod genomes

2

\begin{tabular}{ccccc}
\hline RNA viral clade & Monocondylia & Diplura & $\begin{array}{c}\text { basal } \\
\text { hexapods }\end{array}$ & $\begin{array}{c}\text { Arthropoda } \\
\text { Hepe-Virga }\end{array}$ \\
$\begin{array}{c}\text { Luteo-Sobemo } \\
\text { Narna-Levi }\end{array}$ & $\bullet$ & $\bullet$ & $\bullet$ & $\bullet$ \\
Bunya-Arena & $\bullet$ & & $\bullet$ & $\bullet$ \\
Mono-Chu & $\bullet$ & & $\bullet$ & $\bullet$ \\
Orthomyxo & & $\bullet$ & $\bullet$ & $\bullet$ \\
Nido & & $\bullet$ & & $\bullet$ \\
Partiti-Picobirna & $\bullet$ & & $\bullet$ & $\bullet$ \\
Picorna-Calici & & & $\bullet$ & $\bullet$ \\
Reo & $\bullet$ & & $\bullet$ & $\bullet$ \\
Tombus-Noda & $\bullet$ & & $\bullet$ & $\bullet$ \\
Toti-Chryso & $\bullet$ & & $\bullet$ & $\bullet$ \\
Qinvirus & $\bullet$ & $3 / 24$ & & $13 / 24$ \\
\hline
\end{tabular}

3

4 Note-The presence of RNA viral clade is marked with the black dot.

5

6

7 
Table 5 (on next page)

Comparison of insect and basal hexapod RNA viromes 
Table 5. Comparison of insect and basal hexapod RNA viromes

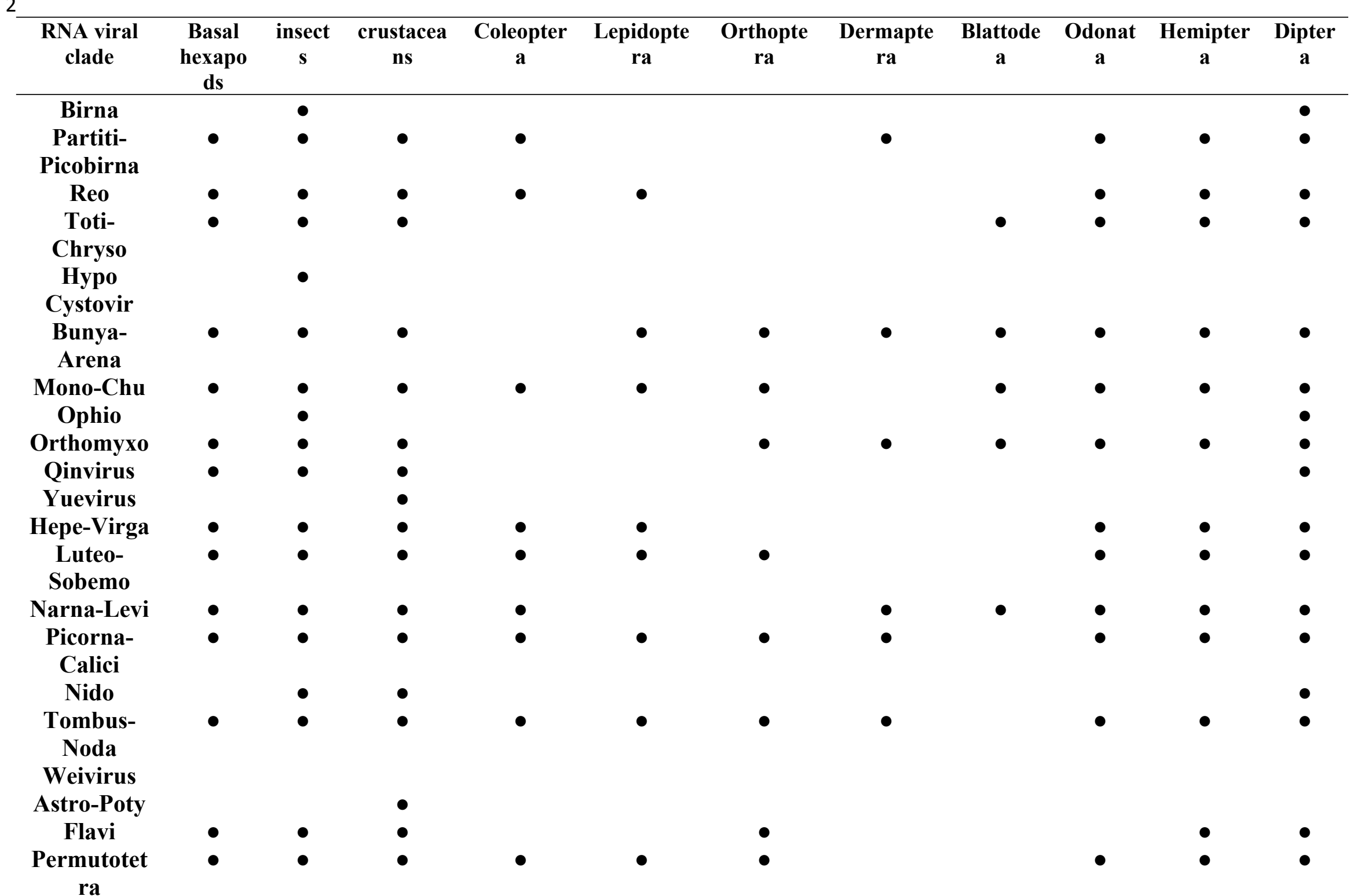


Yanvirus

Zhaovirus

$14 / 24 \quad 18 / 24 \quad 19 / 24$

$9 / 24$

$8 / 24$

$8 / 24$

$6 / 24$

$5 / 24$

$12 / 24$

$13 / 24$

$17 / 24$

Note. - The presence of RNA viral clade is marked with the black dot. Insect and crustacean RNA viral data are from Shi et al. (2016). The data for specific insect orders (Coleoptera to Diptera) are included. 